\title{
Local Government As An Agent Of Transformation In Nation Building
}

\author{
Udunze Ugochukwu McDON \\ udunze_ugo@yahoo.com \\ Department Of Public Administration \\ Nnamdi Azikiwe University, Awka.
}

\begin{abstract}
This paper identified Local government as a veritable instrument towards nation building. It took a look at some of the Local government reforms in the country, examined democracy as catalyst for rural development and how the Local government can spur economic development in the country. We anchored our analysis on collective action theory which viewed the elected representatives as the small group that takes action for the benefit of the entire citizen. We traced the problems of Local government and found out that the Constitution has not done enough for the Local government to be called the third tier government in the country and we suggested for a Constitutional amendment to redress the abnormally and strengthen it for national development.
\end{abstract}

\section{Introduction}

The Local Government in Nigeria is an indispensable tier of government in the Nigerian federal system. It is deeply rooted in the law of the land and derives its powers from the constitution. Section 7(1) of the constitution of the Federal Republic of Nigeria, states that the system of Local government by a democratically elected local government council is under this constitution guaranteed. From the above, it is clear that the local government is backed by law and administratively should have a democratically elected representative of the people who are charged with the responsibility of moving the government towards attaining sustainable growth for national development. Local government can be defined as a political authority which is 
purposefully created by law or constitution for local communities by which they manage their local public affairs within the law/constitution (Ogunna: 1996). The quest for a wide spread development in the country and economic emancipation laid basis for the federal government to create this tier of government which is seen as the closest government to the people. Okoli (2005:) defines local government as a unit of government established by act of law to administer the functions of government and see to the welfare and interest of the local dwellers under the local government system.

Based on the fact that the Federal government sees to the affairs of the entire nation and has many institutions under it which it needs to coordinate and maintain for national growth, it sees the welfare of the local people as paramount and this prompted the need for the creation of local government as the third tier government in the country and charged with the responsibility of uplifting the lives of the rural dwellers. It is important to observe that the basic amenities which are so dear to the people are left in the hands of the local government such as primary health care, rural electrification, pipe borne water, primary education etc.

Laski (1982:411) puts it that,

we can not realise the full benefit of democratic government

unless we begin by the admission that the problems are not the

central problems and that the results of problems not central in

their incidence require decision at the place and by persons, where

and whom the incidence is most deeply felt.

The words of Laski try to inform us that the problems of the rural dwellers differ and are to be tackled on the strength of the problem.

\section{Theoritical Perspective}

Local government in Nigeria as an agent of transformation in nation building and local government as an institution has elicited many write up by many scholars. According to the Local government reform of 1976, it stated clearly that the local government is a government at the local level exercised through representative councils established by law to exercise specific powers within defined areas while Ogunna (1996) sees it as a political authority which is purposefully created by law or constitution for local communities by which the manage their local public affairs within the limits of the law/constitution. As a political authority, the local government is manned by personnel or representatives charged with the responsibility of ensuring that the welfare and affairs of the people are attained. It is the responsibility of these representatives to ensure that the concerns of the people are adequately cared for and administered to ensure bottom to top development in the country. In its drive for nation building, the local government has done well in trying to institutionalise development in their localities through adequate participation towards national issues, policies and programmes. According to Wikipedia, nation building refers to the process of constructing or structuring a national identity using the power of a state. This process aims at the unification of the people within the state so that it remains politically stable and viable in the long run. 
In analysing this work, the collective action theory would be administered to examine the two variables-Local government and nation building. Collective action theory is traditionally defined as any action aiming to improve the group's condition (such as status or power) which is enacted by a representative of the group (Wright 1990). According to this theory, it describes the situation which multiple individuals would all benefit from a certain action. Applying this theory to our study, provision of basic amenities such as good roads, electricity, pipe borne water, primary health care and education etc are the actions executed by the representatives of the group (such as chairmen and councillors) elected at the local government to see to the smooth running of the locality. At the end of the day, the situation where the entire or multiple people would benefit would be an action engineered by a few (representatives).

The economic theory of collective action is concerned with the provision public goods through the collaboration of two or more individuals, and the impact of externalities on group behaviour. it is commonly referred as public choice. Mancur Olson's 1965 book, the logic of collective action: Public Goods and the theory of groups, gives an in-depth analysis of this theory.

\section{Local Government Reforms}

The Nigerian government has done a lot to ensure that the Local government is accorded responsibility and respect in the committee of institution in the country through so many reforms which were properly outlined. The 1976 Local government reform which is generally seen as the reform that gave teeth to the institution and gave rural dwellers a sense of belonging was packaged by the Murtala/Obasanjo administration. The reform for the first time recommended that the Local government be seen as a tier of government and equally provided for statutory allocation for the Local government from the federation account. According to Ogunna (1996), this reform marked a turning point in the history of Local government in Nigeria for so many reasons, namely

I. It was the first reform in the land which took all the Local government in the country into consideration.

II. A uniform system of Local government was for the first time introduced for all states of the federation.

III. The federal government started for the first time to give statutory allocations to the local government.

IV. The Local government were declared as and started to be recognised as "third tier government" with attendant implications.

The reform shows that the local government was granted financial autonomy which made them receive their allocation from share of federal revenue and gave it a status as third tier government thereby granting it autonomy with representatives who are elected by the local dwellers. The reform also brought uniformity of government which allowed all the Local governments in the country to practise the presidential system of government. Regrettably, this reform was short 
lived and was never implemented to the fullest despite the fact that it was enshrined in the 1979 constitution. The Shehu Shagari administration tried to execute the reform in part but did not give more strength towards its enforcement before it was ousted by Gen. Buhari who did not do more towards the uplifting the Local government and has no reform to its credit. The Babangida military administration reviewed the 1976 reform and brought out his own which he implemented and positioned the Local government as centres of socio-economic development ground through out the country. The various Local government headquarters attracted increased and diversified economic, social and political activities. Thus, the Local government is designed to lay a solid political and economic foundation for grassroots socio-economic and political development (Ogunna: 1996).

According to Ogunna (2007), he posited that at the time Babangida left the political scene, he left the Local government with adequate autonomy, sound financial base, educated body of chairmen and councillors, improved executive capacity, appropriate functions and suitable structure. Since after Babangida left office, the subsequent military and civilian administrations have thwarted and stiffened development at the Local governments. The State governments through their state houses of Assembly have made laws that have ridiculed the existence of the Local governments. They control the use of funds at this level through the State/Local Joint Account commissions which was purposefully meant to add value and resources to the Local government by getting some percentage of the state internal generated revenue and add to that of the Local government instead, the State governments and their governors use it as a medium to hijack the Local governments of share of the federation account. In terms of personnel, the State governors have manipulated the Local government to the extent that they appoint their cronies as Care-taker chairman or Transitional committee members as Chief executives at the Local governments without regard to the constitutional provision for a democratically elected Chairman at the Local governments in the country. An example is Anambra state where since 1999, there has not been any Local government election to elect Chairmen and Councillors while in Imo state, the Governor, Owelle Rochas Okorocha sacked elected Local government Chairmen and Councillors whose tenure has not elapsed, although they Chairmen won him at the Appeal court sitting in Owerri, he stood his ground and since then has being using the Directors of administration and general services to oversee to the finance of the Local Governments.

\section{Democracy as Catalyst for Economic Development at the Local Governments.}

Blair (2000: 27) posits that periodic elections provide an important means of ensuring responsiveness and accountability in broad social issues. Democracy is one of the forms of government that guarantees periodic election. Democracy is a system of government and administration whereby people elect their leaders and representatives in a periodic free and fair election. Thus, making the government responsible, responsive and accountable to the people (Ewuim: 2008). Democracy affords elected officers the opportunity to uplift their localities bearing in mind that the electorates are their kits and kin who would jettison them the moment the meagre resources available is diverted or misused. Accountability is assured because a good turn deserves another. Issues of common concern are numerous about democracy making way for democracy. They include; 
(a) It places the citizens on vantage position to learn and understand administrative etiquettes for higher positions in future,

(b) It allows for full participation of the citizens in their local affairs for economic growth and capacity building.

(c) Policies and programmes of government are respected by the localities because the elected the policy makers.

Asogwa Scholastica (2009) believes that for whatever it is worth, democracy recognises that the wish of majority of the people carries the day. The beauty of democracy lies in the fact that the citizens (electorates) are constitutionally conferred with the power to demand for good governance, economic growth and social welfare from their elected representatives and have the power to remove them through voting if their performances are not satisfactory. It enables the representative to sit up and meet the minimum expectations of their people.

\section{Local Government in Economnic Development}

According to President Ibrahim Babangida who rightly puts it that

Growth points must emerge from local government areas and

provide the much needed push to activate and energise productive

activities in rural Nigeria and to reverse the phenomenon for

rural-urban drift.

The local government ensures that the local areas must be seen as a point where development should emerge and spread to the entire nation. To ensure that the Local is adequately funded for economic growth, many forms of revenue has be adopted and implemented but were all dropped because of their inherent deformities like favouritism, non compliance, inequalities etc but with the 1976 reform gave room for statutory allocation from federation account which makes it criminal to withhold their funds which are giving to ensure that the welfare of the local people are administered. By so doing, it places itself as the best institution and tier of government that encourages even development in the country.

These are some of the areas the Local government use to drive national development.

(a) Agriculture: Before the discovery of oil in Nigeria in commercial quantity, Agriculture was the main stay of the economy. With agricultural advancement a nation launches itself into one of the leading economies in the world. According to Okonko (1995), any country that is unable to feed itself should not regard itself as developed. The importation of even the stable food for the citizens should be seen as a national disgrace. The interesting thing about agriculture is that it is an end to end profit making venture which engineers rapid development from the grassroots. The distribution of farm implement like fertilizer through this level of government encourages farmers and makes it accessible by them. Researchers believe that $70 \%$ of Nigerian labour force is employed in agriculture and they live in the rural areas. In fact, the Local government is a sound base through which food sufficiency could be attained with the aid of the Federal government and this would create employment and curtail rural-urban migration which leads to prostitution, armed robbery, kidnapping and other vices. 
(b) Sensitisation and mobilization: The Local government as the closest government to every citizen avails the Federal government the opportunity to tap into for sensitising and mobilizing the people. Nnamani (2012:110) believes that political participation serves the following functions in a political system:

- Exposes the political issues and situation to both the rulers and the ruled.

- Affords the people the opportunity to express their opinion

- Exposes the greatest opportunity for majority.

- Creates order and stability on the system.

In Nigeria today, there is a disconnect between the people and government because the Federal government has not only crippled the Local government system but has allowed the State governments to make experiments with it thereby misinforming the people on the objectives of the local government. The Local government serves as a centre where the local people come and get informed about the policies of government and their own input towards government programmes. Any nation that does not accord respect to the rural people through adequate information of governments' vision has done well to deform the largest number of its citizens.

(c) Infrastructural development: According to Bhatia (2011), an adequate and efficient infrastructure is a pre-condition for a suitable and rapid economic growth and is a major source of external economies. The local government in the country receives the least allocation in the federation and this has not given them the needed resources to erect structures that could stand the test of time. Infrastructure could equally be seen as a barometer to measure development. The local governments in the country afford the federal government an institution were where funds could be utilised to fund housing estates and construction of roads etc.

(d) Health: Today in Nigeria, Local government is recognized as a stand point for promoting good health in the country most especially in the area of primary health care. Health workers at the Local government through out the nation have been used in the immunization campaign to fight polio and other childhood killer diseases thereby safe guarding the lives of the younger ones who are told that they are the leaders of tomorrow. The constitution of the federal republic of Nigeria in the Fourth schedule, Section 7(2) further gave more responsibilities to the Local government on health matters when it stated that the functions of a local government council shall include participation of such council in the government of a state as respects the following matters... (c) provision and maintenance of health services and (d) other of such functions as may be conferred on a Local government council by the house of Assembly of the state. From the above, it implies that Local government is legally an institution responsible for health services and care for the citizens. This government is in a pole position to know when any epidemic occurs in their areas, get information, diagnose patients and give them the necessary health attention the require and through the health workers vaccinate the people of the area to stop the spread.

\section{Problems of Local Government towards National Development}


The local government as the tier and grass root government in Nigeria have really suffered in the hands of the upper governments and in the hands of its officials who are representative of the local people. The problems this government encounters include,

(i) Paucity of fund: The constitution empowers the local government to source fund through tax, rates, fees etc around its jurisdiction and on its people but the state governments has taken over some these major sources of revenue and leased to their cronies at little or no price. Further more, the constitution mandates the state government to pay in $10 \%$ of their internal generated revenue to the State Joint local Government Accounts purse for disbursement by the local governments in the state instead the use this avenue to siphon local government funds that come into the same account thereby rendering it helpless and lacking in fund to execute their duties such as construction and maintenance of roads, streets, street lights, pipe borne water etc.

(ii) Peace and Stability: Peace is the plume value in contemporary Nigeria, the most valuable public good, but yet the most elusive, Uche (2011). Development and growth in the local government was drawn backwards due to lack of peace and stability in government. Some of the military administrations we had in this country lacked focus and vision: looked at the local government as an institution to settle some powerful elites who nominate their loyalists as sole administrators and this normal caused crisis in the area because the people they nominate are not always the wish to people and they also encounter public rejection. Today, the Governors of many states have done worst than the military administrators, changing the chief executives whom the hand pick at will without recourse to the law.

(iii) State over bearing influence: The state governments in our present democracy has ridiculed this system and makes bold to say it is an off shoot of the state and has no autonomy. They now stand down on the laws establishing the local government, controls their funds, use the state house of Assembly to make laws that deducts local government fund etc.

(iv) Flagrant abuse of rule of law: Section 1(1) of the constitution of the Federal Republic of Nigeria states, this Constitution is supreme and its provisions shall have binding forces on all authorities and persons throughout the Federal Republic of Nigeria. It is rather unfortunate that some State governors has against section 7 (i) of the same constitution which states that a local government by democratically elected local government council is under this constitution guaranteed. Today the local government is no longer a place where the masses elect their representatives who know their problems and attend to them but a place where the Governors exercise their powers thereby disconnecting the people from activities of government and reducing the flow of growth and economic development.

(v) Corruption: This one major canker that has ravaged the Nigerian system. The Local government officials has adversely undermined development in their areas and 
reduced the faith the Federal government has on it. The staff of the Local government has seen this institution as avenue to enrich themselves as it brings the "national cake" closer to them. They have equally neglected the ethics of service and compromised standards thereby making themselves agents of destruction and conduit pipe to siphon public fund. Indiscipline, truancy and kickback has not only taken over the activities of the government but has is now regarded as a culture. Projects which are of benefit to the people are poorly executed because a large chunk of the money has been taken as kickback by government officials and the Contractor is left with little fund to execute the contract. Recruitment exercise is no longer advertised rather applicants are hand picked, favour dispensed to acolytes with thoughtless abandon, settle party loyalist, girl friends and make money through it thus sacrificing merit and competence on the alter of mediocrity.

All these challenges form part of the things that have stalled development at the Local government in Nigeria.

\section{Repositioning the Local Government as Catalyst for Nation Building in Nigeria}

The Local government is a veritable institution in the Nigerian polity, well positioned and backed up by the constitution. Many successive administrations has given a touch to the Local government through various reforms most notably is the 1976 reform instituted by the Murtala/Obasanjo administration but all have come out to be paper work without implementation. This paper has tried to highlight some spots if solved would help in solving some inadequacies prevalent at this level of government.

The Constitution which created the Local government is the worst enemy of this government. The Constitution which made it clear that the Local government is the third tier government in the country, as such independent of other tiers unfortunately through its fourth schedule empowers the State Houses of Assembly to make laws for the Local government. This is indirectly placing the activities of the Local government in the hands of State government and runs foul to the autonomy granted them. The Fourth Schedule should be amended and those powers be placed in the Council who are elected representatives of the people at the Local governments.

The same Constitution empowers the State governments to organise Local government elections. This is the crux of the matter. It is evident that since the local government election is organised by the State governments through the State Independent Electoral Commission, they will manipulate them and ensure that their party wins all the elections. President Goodluck Jonathan gave strength to this when he openly declared,

...the way the Governors are handling elections in their states with the State Independent Electoral Commissions, where opposition parties hardly win even councillorship elections...(Nnochiri: 2012). 
From the Presidents comment, it is clear that what goes on as election can only be described as selection. In some cases, the State governments decides not to hold Local government election so that the will manipulate those they would appoint. A State like Anambra has not conducted Local government election since the inception of this present democratic dispensation that began in 1999 and this has not only affected the psyche of the local people but also erased grass root development, sensitization and political culture. The issue of Local government election should be left in the hands of the Independent National Electoral Commission (INEC) charged with the responsibility of conducting elections as at when due.

Local governments as agents of transformation and Nation building must be allowed to make use of its scarce resources to develop their areas and not being siphoned through the State Joint /Local government Accounts by State governments which have crippled its activities. It is advised that the various Local governments in the Country should open accounts with the Revenue Mobilisation and Fiscal Commission where their own share from federation account would come to without diversion and their own percentage of State internal generated revenue added to it. The signatories to this account should be the democratically elected Chief executive of the Council and the Director of Administration and General services of the Local government.

The revenue base of the Local governments should be widened: provide legislation that would help them tax companies, banks and institutions located in their areas.

Political culture and participation should be strengthened where every citizen should learn and know how a government runs its activities and be able to contribute towards nation building.

The Local government should be allowed to recruit its entire staff from the lower cadre to the higher cadre and put a stop to incidences where State governments send their acolytes as Treasurers or Directors of Administration and General Services to them just to have an eye on the Local government purse.

The Local government Council should be stocked with educated and enlightened Representatives who would make laws that are capable of strengthening and creating avenues for economic and social development of their areas and not citizens who are elected based on sentiments which have murdered professionalism and promoted inefficiency at the grass roots.

\section{Conclucion}

The Local government as the third tier government in the Nigerian federation was born out of the clear need to better the lots of local citizens in the country. As an agent of transformation, it has unarguably gone through much process that has placed it on the part of growth and sustainable development in Nigeria. However, its strength lies on the leadership of the country from the Executive (Presidency) to the Legislature (National Assembly) down to the Judiciary. These public officials should ensure that the laws governing the Local government should be in the exclusive list and not con current list that allows the State governments to lay claim over this level of government and the laws been made be strictly enforced and offenders be slammed with the instrument of law. Since the Local governments are given essential services to provide for the 
people, efforts should be made to ensure that the funds meant for these purposes be released in time and channelled to the appropriate quarters. A well packaged and articulate plan for Local government in the country would reduce criminality, unemployment, rural-urban drift and encourage economic, agricultural growth and political education attained.

\section{Refrences}

Asogwa Scholastica N. (2009) Nigerian Citizenship education: A matter of the constitution and the law, John Jacob's Classic publishers Ltd, Enugu.

Bhatia H. L. (2011) Public Finance Vikas Publishing House PVT Ltd. New Delhi.

Blair Harry (2000) Participation and Accountability at the periphery: Democratic Local governance in six countries. World Development.

Constitution of the federal Republic of Nigeria (1999) with amendments 2011.

Ewuim Ngozi (2008) Succinct Approach to Government: A comparative Analysis. Mount Camel Printing and Publishing

Federal Republic of Nigeria (1976) Guidelines for Local Government Government Printer.

Reforms, Kaduna:

Laski H.J. (1982) A Grammar of Politics. London, Allen and Unwin

Nnamani L.C. (2012) Fundamentals of Political Science, John Jacob's Classic Publishers Ltd, Enugu.

Nnochiri, I (2012, September 9) Nigeria not ripe for State Police-

Jonathan declare, Sunday Sun.

Oguuna A.E.C. (1996) A handbook on Local government in Nigeria, Versatile publishers, Owerri.

Ogunna A.E.C. (2007) Basic issues in Community Development and Local government, Versatile publishers, Owerri.

Okeke J Ka-Anayo et al (ed) (1995) Ideas in Development: a multi- disciplinary overview, Creative Education management consultant, Owerri.

Okoli M.U (2005) Local Government Administrative system: An Introductory and Comparative Approach. Abbots books ltd, Onitsha. 
Tunji Olagunji and Sam Oyovbaire (eds) (1991) For their tomorrow, We give our Today, Safari books, Ibadan.

Uche, O.O.C. and Okeke S.C. (2011) Nigerian History, Culture and Socio-Political Development, EAP Publishers Enugu.

Wright, S.C (1990) Responding to membership in a disadvantaged group: From acceptance to collective protest. Journal of Personality and Social Psychology. 